Journal of Theoretical and Applied Economics
(ISSN:2576-3970)

\title{
SERVICE QUALITY MEASUREMENT MODELS: A Comparison of
} Two Models

\section{Asmerom A. Ghebremichael ${ }^{1}$ and Fitsum Ghebregiorgis ${ }^{2}$}

${ }^{1}$ Department of Accounting at College of Business and Economics, Department of Accounting (Previously at the University of Asmara. Now under the umbrella of the National Commission for Higher Education, Eritrea) ${ }^{2}$ Department of Business Management and Marketing at College of Business and Economics, Department of Business Management and Marketing (Previously at the University of Asmara. Now under the umbrella of the National Commission for Higher Education, Eritrea)

\section{ABSTRACT}

Purpose of this paper: This study aims to contribute to the debate in service marketing literature concerning the operationalisation of service quality measurement. To this effect, we tested two service quality measurement models by adapting them to the audit service context. These models are the gap model (SERVQUAL) developed by Parasuraman, Berry, and Zeithaml (1985) and the performance-only (SERVPERF) model developed by Cronin and Taylor (1992). Design/methodology/approach: The models are quantitatively analysed and evaluated for construct validity and predictive power using OLS models. In line with marketing literature (Gronroos 1984), service quality dimensions are classified into technical and functional dimensions. Construct validity is measured in terms of whether the technical and functional dimensions of audit service quality are significantly positively correlated with an overall measure of service quality in the audit service market. Predictive power is measured in terms of the strength of adjusted R2. Findings: The results indicate that both the performance-only model and the gap model have done quite well in predicting determinants of overall audit quality. The argument by Cronin and Taylor (1992) that the gap model has low explanatory power compared to the performance-only model did not materialise in our study. Research limitations/implications: Our results are limited by the low response rate that did not allow us to conduct factor analysis on all the functional and technical variables at the same time. What is original/value of paper: The paper shows that the service marketing models for the measurement of quality would be improved when core outcome (technical) variables are incorporated.

Keywords: Service quality, SRVQUAL, SERVPERF, Technical quality, Functional quality,

\section{*Correspondence to Author:}

Fitsum Ghebregiorgis (address for correspondence), College of Business and Economics, P.O. Box 3963, Asmara, Eritrea (Tel: + 291716 1013).

How to cite this article:

Asmerom A. Ghebremichael and Fitsum Ghebregiorgis. SERVICE QUALITY MEASUREMENT MODELS: A Comparison of Two Models. Journal of Theoretical and Applied Economics, 2017; 1:3.

\section{eSciencePublisher}

eSciPub LLC, Houston, TX USA. Website: http://escipub.com/ 


\section{INTRODUCTION}

Consumers make buying decisions and cling to product brands due to perceptions of quality (Boshoff, Mels, and Nel 1994). Consequently, perceived quality is one of the important reasons why customers engage in a relationship with a supplier. As a result service firms have been repeatedly cautioned about the importance of quality to their customers (Boshoff, et al. 1994, Zeithaml, et al. 1996). Studies have reported that quality has apparent relationship to many facets of competitive advantage such as costs, profitability, customer satisfaction and retention, market share, and return on investment (Mosahab et al. 2010; Sachdev and Verma 2002; Zeithaml 2000; Zeithaml et al. 1996; Richard and Allaway 1993). Accordingly, firms have used quality in order to gain these advantages. Unfortunately, research on quality and its relevance for service firms has been hampered by the lack of a generally acceptable definition of the concept (Boshoff, Mels, and Nel, 1994). This in turn has hampered the development of a generally acceptable service quality measurement instrument.

While the quality of tangible goods has often been described and measured objectively and considerably by researchers, service quality has largely remained difficult to assess because of its subjective nature. As Parasuraman, Zeithaml, and Berry (1988) described it service quality by its very nature is an abstract and elusive construct. Consumers find it hard not only to measure and delimit the concept, but difficult to articulate their requirements as well. For this reason, sellers of services experience difficulty in understanding and controlling quality. Zeithaml et al. (1988) stated that services are performances rather than objects and, therefore, precise manufacturing specifications for uniform quality can rarely be established and enforced by the firm. This means that, unlike goods, service quality is not engineered at the manufacturing plant, then delivered intact to the consumer. Service quality can not be assured by counting, measuring, testing, and verifying in advance of the sale. Furthermore, in most services especially in those with high labour content (such as audit firms), quality occurs during service delivery, usually in an interaction between the customer and the contact personnel of the service firm. This causes the performance of services to often differ among employees, among customers, and from day to day. As a result, 'service quality is highly dependent on the performance of employees, an organisational resource that can not be controlled to the degree that components of tangible goods can be engineered' (Zeithaml et al. 1988; 35). Thus, in the measurement of service quality, one has to recognise that assessment is made not only on service outcome, but also on the process of service delivery. Consequently, service quality is a multidimensional construct with broad dimensions classified as technical and functional dimensions (Lehtinen and Lehtinen 1991; Grónroos 1984). The technical outcome of the service is what consumers receive as a result of their interactions with a service provider. However, the customer is also interested on how the service was or is being provided in addition to the technical outcome of the service. How the waiters behave in a restaurant business, the courtesy of flight attendants in an air transportation, the equipment used by a transportation company in the delivery of goods, the way auditors communicate with their clients, the responsiveness of business consultants to the problems of their clients, etcetera, all have an impact on the customer's view of the service. Grónroos (1984) referred to this dimension of service quality as the functional quality dimension.

The remainder of the paper is organized as follows. Section two presents the theoretical background of the efforts made to define service quality and the attempts made to develop service quality measurement instruments. Section three develops and discusses the audit quality 
Asmerom A. Ghebremichael and Fitsum Ghebregiorgis, JTAE, 2017; 1:3

construct. The audit service market is used in this study to test which of the two service quality models identified in section two is superior. In this section, literature on the economics of auditing, audit quality, and service marketing is reviewed in an attempt to define the audit quality concept and to identify its dimensions. Section four develops the hypotheses on the determinants of overall audit quality. Section five presents the methodology used to collect and analyse the relevant data. Section six presents the empirical findings of the study. Finally, in section seven we discuss and conclude on the findings.

\section{DEFINING AND MEASURING SERVICE QUALITY}

An understanding of the characteristics of the service sector is necessary in the selection of an appropriate instrument to measure service quality. Such an instrument needs to accommodate the difficulties and peculiarities raised in the previous sections. Service output is characterised inter alia by high involvement of the consumer, which leads him/her to a greater noticing of the process (Lehtinen and Lehtinen 1991; Grónroos 1984). As a result, the quality construct as conceptualised in the service literature centres on consumer perceived quality (Parasuraman et al. 1988; Grónroos 1984). This implies that, in the service industry, quality measurement seems to be in terms of the result of the comparison that customers make between their expectations and perceptions about the service (Landrum, et al., 2008; Zeithaml et al. 1988; Caruna, et al., 1998; Grónroos 1984). Grónroos stated that "...the perceived quality of a given service will be the outcome of an evaluation process, where the consumer compares his expectations with the service he perceives he has received, i.e. he puts the perceived service against the expected service. The result of this process will be the perceived quality of the service" $(1984$, p37). Parasuraman et al. (1985) also state that service quality measurement is made based on a comparison between what the customer feels should be offered and what is provided. Accordingly, Parasuraman et al. (1988:1) define perceived quality as "the degree and direction of discrepancy between consumers' perceptions and expectations".

Grónroos (1984) argues that there are many factors that influence the expectations of a customer among which are traditional marketing activities (such as advertising, field selling, pricing, etc.), previous experience with a service, ideology, and word-of-mouth communication. The perceived service, on the other hand, is the result of the consumer's perception of how the service was performed. Hence, the quality of the service is dependent on two broad variables: expected service and perceived service. Quality can, then, be measured by comparing the expectation of clients with their perception of the actual service performance.

Although Grónroos's conceptualisation of service quality was the first to be aired in the academic literature, it has been the work of Parasuraman, Zeithaml, and Berry $(1985,1988,1991 a)$ in developing and promulgating a technology for measuring and managing service quality which has received the most attention (Grapentine 1998). Since then, a number of studies have tried to operationalise theoretical frameworks and introduce various methodologies for the measurement of service quality in various service sectors by selecting a suitable definition of quality (e.g. Cronin and Taylor 1992; Bolton and Drew 1991). The technology that Parasuraman et al. has developed is called the SERVQUAL model. The model is based on what is termed as "gap analysis" in the provision of services. That is, service quality can be assessed by comparing customers' expectation of the service prior to the service encounter and their perceptions of the actual service delivered. This notion can be reflected in the equation:

$$
\text { Quality }=f \text { (Gap). }
$$


Asmerom A. Ghebremichael and Fitsum Ghebregiorgis, JTAE, 2017; 1:3

Perceptions of performance are consumers' beliefs, based on experience of how well (or how bad) a service has been performed by the provider whereas expectations are consumers' feelings concerning how a service should be provided (Caruna et al. 1998). Parasuraman et al. (1985) argue that the higher the expectation of the consumer the lower will be the quality of service unless matched by an equivalent or greater magnitude of perceived performance by the service provider. The resulting difference between performance and expectation is the gap that ultimately indicates the perceived level of quality.

The SERVQUAL model (gap model) measures service quality using a 22-pair of items that are claimed to have resulted in the five dimensions. That is, 22 items are used to capture consumers' expectations from the service provider. At the same time the performance of the service provider is measured using these 22 items with some changes in the wording. The measurement can be made on the basis of a five, seven, or nine-point Likert scale. The gap between the performance scores and the expectation scores on these items is then used to evaluate service quality. The working presupposition is that the service is good if performance meet or exceed expectations and problematic if performance falls below expectations.

The development of the SERVQUAL model started with the establishment of the aspects that the customer values in assessing service quality. To identify these aspects, Parasuraman et al. (1985) undertook a comprehensive review of the literature on service industries, and conducted focus group interviews with customers of four industries, namely retail banking, credit cards, securities brokerage, and product repair and maintenance. Parasuraman et al. analysed the results and conclude that customers use the same measuring standards in assessing service quality regardless of the type of industries, and that their criteria correspond to ten overlapping dimensions.
These ten dimensions were: tangibles, reliability, responsiveness, competence, courtesy, credibility, security, communication, access, understanding the customer. Parasuraman et al. then drew up 97 questionnaire items that correspond to these ten items, and refined them to reduce the number of items based on the industry survey results. This was done based on Cronbach's alfa value of each dimension as well as on the item to total correlation coefficients. At the same time, the number of items was condensed through factor analysis. Parasuraman et al. passed through stages of seven dimensions and 34 items, and five dimensions and 26 items, and finally settled on the five dimensions of tangibles, reliability, responsiveness, assurance, and empathy with corresponding 22 questionnaire items. The developers of the instrument claim that SERVQUAL with its five dimensions and its corresponding items "capture facets of all ten originally conceptualised dimensions" (Zeithaml et al. 1990) and could be widely utilised in any industry with only minor modifications (Parasuraman et al. 1991a).

The SERVQUAL model is the most popular service quality measurement instrument that has been extensively applied for various services (e.g. Ravichandran et al., 2010; Mosahab et al. 2010; Sachdev and Verma 2002; Urdang and Howey 2001; Nel, Pitt, and Berthon 1997; Dassen 1995; Richard and Allaway 1993; Bojanic 1991). However, several researchers have recognised that both the instrument itself and the conceptualisation of service quality may benefit from further refinement. Service quality evaluations involve both technical (outcome) and functional (process) attributes. However, the gap model focuses mainly on the functional attributes of quality and this is a major shortcoming (Buttle 1996). Models that utilise only functional quality attributes to measure overall quality may be 'misspecified and have low predictive validity' (Richard and Allaway 1993: 60). However, 
Nagata, Satoh, Gerrard, and Kytómaki (2004) argue that the functional quality is appropriate where the technical quality stays much the same.

Richard and Allaway (1993) augmented the gap (SERVQUAL) model by including six items assessing outcome quality increasing the original attributes to 28 . To compare the prediction ability of the functional-only model and the functionaltechnical model, they conducted a regression analysis of attributes of both models using data from 139 adult respondents of pizza consumers. Their result indicated that the model with both functional and technical (outcome) quality attributes is superior in terms of predicting service firm choice as compared to the functional-only model or outcome-only model. The criticism that the gap model only measures attributes of process quality and ignores technical (outcome) quality is consistent with that of Woo and Ennew (2005) and Carman (1990). Carman offered only a mild support for the dimensions proposed by the gap model suggesting that the five generic dimensions be considered as a starting point only on which to add dimensions to improve usefulness.

Another major criticism of the gap model was made by Cronin and Taylor (1992). The primary concern of these researchers was that the model's 'expectations' component is unnecessary and its dimensionality is problematic. Cronin and Taylor argue that the relevance of the expectationperformance gap as the basis for measuring service quality is not sufficiently supported by theory or empirical evidence. Babakus and Boller (1992) also stated that the expectationperformance gap approach to service quality management seems intuitively appealing but questioned the ability of the difference scores to provide additional information beyond that already contained in the 'perceptions' component of the gap model. They also argue that the contributor to the gap score was the perceptions score because of a generalised response tendency to rate expectations high. Cronin and Taylor conducted a study in four service industries to investigate whether a performance-only instrument of service quality measurement is superior to the expectation-performance gap model. On the basis of this study, Cronin and Taylor (1992) contend that in all industries surveyed, the performanceonly instrument (which they called SERVPERF) explains more of the variations in the global (overall) measure of service quality. Thus, Cronin and Taylor (1992) concluded that the gap model's expectation component is unnecessary, although this conclusion has been challenged by Parasuraman et al. (1994) in an article they wrote in response to Cronin and Taylor and Teas (another critic of the model). In this article, Parasuraman et al. (1994) argue that high performance on an attribute does not necessarily indicate high quality because it may not be high enough from the customer's standpoint; hence the customer's expectation component is an important norm.

The claim by Parasuraman et al. (1988) that the 22-item scale and its five dimensions are generic across service contexts has also raised a number of significant questions (Cronin and Taylor 1992; Babakus and Boller 1992; Francis 1996; Stank, Goldsby, and Vickery 1999). When the gap model was employed in different service sectors in a modified form, many distinct dimensions of service quality were revealed (Francis 1996). Babakus and Boller (1992) commented that 'the domain of service quality may be factorially complex in some industries and very simple in others'. Thus, they claim that the number of service quality dimensions is dependent on the particular service being offered. Cronin and Taylor $(1992 ; 65)$ also suggest that 'the scale item that define service quality in one industry may be different in another. Perhaps high involvement (contact) services [...] have different service quality definition than low involvement (contact) services [...] researchers therefore must consider 
Asmerom A. Ghebremichael and Fitsum Ghebregiorgis, JTAE, 2017; 1:3

the individual dimensions of service quality [...]' (word in parentheses added).

In their 1988 work, Parasuraman et al. defined 'expectations' as 'desires or wants of consumers, i.e. what they feel a service provider should offer rather than would offer'. The 'expectations' component was designed to measure customers' normative expectations (Parasuraman et al. 1990). Teas (1993a; 1993b) argue that this definition of expectations is somewhat vague and has questioned respondents' interpretation of the 'expectations' component in the gap model. Teas (1993a) contend that a considerable percentage of the variance of the gap model expectations measure can be explained by the difference in respondents' interpretations. Following the results of a number of replication studies, Parasuraman et al. (1991b; 1994) have responded to these criticisms by redefining expectations as the service customers would expect from excellent service organisations', rather than 'normative' expectations of service providers.

In a different concern, Teas (1993a) also questioned the meaningfulness of the model's 'performance minus expectation' specification. Teas (1993a) argue that the specification is meaningful only if the service feature being assessed is a vector attribute. ${ }^{1}$ The gap model assumes that customers are likely to consider the 22 items as vector attributes. However, Teas' (1993a) concern that the model's 22 items may be classic-ideal-point attributes-that is, one on which a customer's ideal expectation is at a finite level, in which case the 'performance minus expectation' specification becomes problematic. In a classic-ideal-point (expectation) attribute assumption, performance beyond the customer's ideal point displeases the customer, giving rise to a decrease in quality. However, Parasuraman et al. (1994) responded stating that 'for a vast majority of the respondents, the vector-attribute assumption is tenable' even for the service attributes included in Teas's (1993a) study.

In spite of a number of concerns and shortcomings, the gap model has showed particular strength in the representation of functional quality (Woo and Ennew 2005). It has also been shown to be a reliable and valid measure of service quality with relatively stable dimensions across service industries (Parasuraman et al. 1988). It also has proved to be very popular and has generated much research and application across different industry sectors and countries (e.g. Sachdev and Verma 2002; Urdang and Howey 2001; Nel, Pitt, and Berthon 1997; Dassen 1995; Richard and Allaway 1993; Bojanic 1991).

Several researchers have adapted the items in the gap model to develop alternative measures that are argued to overcome the problems associated with the conceptualisation of service quality as a difference score (Stank, et al. 1999). As discussed earlier, the expectation-performance gap as the basis for measuring service quality in the gap model was criticised by Cronin and Taylor (1992) and Babakus and Boller (1992). Both groups of researchers argue that the expectations component of the gap model is not sufficiently supported by theory or empirical evidence. The performance-only measure of service quality is argued to be the best measure for a continuously provided service (Cronin and Taylor 1992; Oliver 1989). Cronin and Taylor (1992) dropped the expectations component of the gap model and applied only the performance component. Cronin and Taylor conducted a study in four service industries to investigate whether a performanceonly instrument of service quality measurement is superior to the gap model. On the basis of this

\footnotetext{
${ }^{1}$ Vector attribute is one on which a customer's ideal expectation is at an infinite level. That is, with vector attributes, performance higher than expectation is always preferable.
}

Http://escipub.com/journal-of-theoretical-applied-economics/ 
Asmerom A. Ghebremichael and Fitsum Ghebregiorgis, JTAE, 2017; 1:3

study, Cronin and Taylor (1992) contend that in all industries surveyed the performance-only instrument (which they called SERVPERF) explained more of the variations in the global (overall) measure of service quality than the expectation-performance gap. Thus, Cronin and Taylor (1992) concluded that the model's expectation component is unnecessary. The model is expressed in the following equation:

\section{Quality $=f$ (Performance)}

Where 'Performance' is the perception of service users about the performance of the service provider on identified quality attributes.

In view of the foregoing debate the following research questions are put forward:

1. What are the determinants of overall service quality in the audit service market?

2. Based on the identified determinants of overall audit service quality which of the two service quality measurement models (gap model and performance-only model) is superior in terms of construct validity and predictive power.

In this study, the quality construct is measured in terms of its technical outcome and functional aspects of the audit service market. Following the dominant definition of service quality in the marketing literature, the perceptions of supervisory board members on the technical and functional attributes of audit service quality are used in this study to measure service quality. Audit service quality is measured using the two dominant service quality measurement models, the gap model (SERVQUAL) and the performance-only model (SERVPERF).

\section{AUDIT SERVICE QUALITY}

Audit service quality has been one of the most important issues facing the audit profession. Investors, lenders, and other stakeholders need reliable information generated by companies for sound economic decision-making. Generally, external auditors give services in the areas of information risk management, attestation of historical financial statements, systems design and development, and internal control assessments for efficiency and effectiveness. The value of these services depends, among other things, on the quality of the audit firm that executes the engagement. Despite its importance and the various approaches used to examine it, audit quality is not explicitly defined and little is known about the factors that are perceived to affect it. Like in many other services, audit quality is characterised by a strong ambiguity that makes it hardly observable, definite, and measurable (Wooten 2003; Herrbach 2001). Audit service is characterized by intangibility of output for which precise specifications for the uniform quality of its output are difficult, if at all possible, to set. It is also characterized by inseparability of the provision and consumption of the service. And finally, different users of, and parties to, the service may have different expectations and perceptions for the same service. The above characteristics make it impossible for users like supervisory directors to make an ex ante assessment of factual audit quality because of limited access to important variables (Knapp 1991). Several studies have applied a behavioural approach in understanding and measuring audit service quality (e.g., Duff 2004; Morton 1998; Warming-Rasmussen and Jensen; Dassen 1995; Carcello, Hermanson, and McGrath 1992). Following these studies, we identify attributes of audit quality based on the perception of one group of audit service users, supervisory board members of large and medium corporations in the Netherlands. We then investigate which attributes are the most important determinants of perceived overall audit quality. Therefore, this paper, in part, tries to answer the questions "what are the determinants of perceived overall audit quality?"

In the economics of auditing literature researchers have focused only on the technical dimension of audit quality (DeAngelo 1981; Watts and Zimmerman 1981). These researchers try to link 
Asmerom A. Ghebremichael and Fitsum Ghebregiorgis, JTAE, 2017; 1:3

technical audit quality to the risk of detecting and disclosing material misstatements in the financial statements (DeAngelo 1981). Accordingly, DeAngelo (1981) defines audit quality as the likelihood that material misstatements in the financial reports will be discovered (auditor competence) and that auditors will report these misstatements (auditor independence).

DeAngelo's (1981) definition seems to imply that audit quality is assessed based on the perception of the market as to whether a given auditor is competent and independent enough to minimize the cost associated with agency conflict. Following this argument, it is the perception of the principal (mainly supervisory directors as representatives of shareholders) and not the preparers of accounting information that is more important in evaluating audit quality. However, because competence and independence are difficult to observe, third parties often use surrogates to relate them with these unobservable quality dimensions. Some of the surrogates used in these studies are: audit firm size/brand name reputation (Krishnan and Schauer 2000; Craswell, et al. 1995; Knapp 1991; Palmrose 1988; DeAngelo 1981); auditor tenure (Carcello and Nagy 2004a; Vanstraelen 2000; Knapp 1991); industry specialisation (DeFond et al. 2000; Deis and Giroux 1992); audit fee premium (Simon 1997); auditor litigation (Palmrose 1988); and voluntary membership in peer review programs (Deis and Giroux 1992). As a result, these studies do not take into account the functional (relational) aspect that is inherent to the provision of audit services as there seems to be a continuous nature of relationship between a client and an audit firm. For the supervisory directors, this relationship is mostly apparent at the time of communicating the findings of the audit, when the supervisory directors need clarifications on certain issues and questions, as well as in the auditor's role in crisis situations. The engagement partner plays a greater role here as contact of the supervisory directors is usually with the audit partner rather than with the audit team. Therefore, the definition of quality in terms of the agency problem should thus be integrated with the functional aspect of quality.

An integrated literature review in the economics of auditing and expectation-gap studies has enabled us to identify attributes of auditor competence (detection ability) and independence (willingness to report). Furthermore, from the behavioural audit quality and marketing literature we identified those attributes that determine the functional aspect of the audit service process. Therefore, we measure audit service quality in terms of auditor competence, auditor independence, as well as functional dimensions.

As part of the development of a valid measure of quality attributes, Churchill (1979) suggests that an experience group be involved in the attributes identification procedure. Consequently, the attributes we identified were presented to two highly experienced supervisory directors and seven audit partners for discussion on their relevance for supervisory directors' perception of audit service quality. A total of 76 attributes of audit service quality were presented to the experience group for discussion. The experience group indicated that the attributes identified have different levels of relevance for supervisory directors. Accordingly, the items that most of the interviewees agreed to be highly (and moderately) relevant are selected for our survey.

The discussion on the attributes identified from the literature together with some new attributes suggested by the interviewees resulted in 43 attributes. Subsequent discussions with two auditing professors, and a pre-test of the questionnaire resulted in nine additional attributes, making a total of 52 audit quality attributes. Out of the total number of attributes 25 are related to the technical dimension and 27 to the functional dimension. The result of these exploratory interviews has enabled us to identify 
the attributes that are incorporated in the final survey instrument.

\section{HYPOTHESES ON THE DETERMINANTS OF OVERALL AUDIT QUALITY}

\section{Functional audit quality}

The perceptions of supervisory directors can be influenced by the interactions they have with the audit firm's personnel (mainly with the audit partner). Theoretical and empirical studies (Morton 1998; Dassen 1995; Bojanic 1991; Lehtinen and Lehtinen 1991; Parasuraman et al. 1988 and 1985; Grónroos 1984) have argued that there is a positive relationship between functional audit quality attributes and the overall assessment of audit quality. Indeed functional quality may be important to the extent of offsetting technical quality problems (Saleh and Ryan 1991). Thus, we hypothesise in this study that:

HYPOTHESIS 1A: Functional quality dimensions identified using the gap model (SERVQUAL) will have a significant positive correlation with perceived overall audit quality.

HYPOTHESIS 1B: Functional quality dimensions identified using the performance-only model (SERVPERF) will have a significant positive correlation with perceived overall audit quality.

\section{Technical audit quality}

Ensuring technical audit quality is one of the mechanisms for minimizing the effect of the agency problem that arises because of information asymmetry. As representatives of the principal (stakeholders), it is an essential part of the supervisory board's oversight role to ensure the provision of an objective disclosure of financial information (Jensen and Meckling 1976). Therefore, a higher perception of auditor performance on the technical quality dimensions will have a positive effect on the supervisory directors' assessment of overall audit quality. Dassen found a positive relationship between the detection ability of auditors and overall assessment of audit quality for both clients and bankers (Dassen 1995). Marketing literature also suggest a positive influence of technical quality on the assessment of overall quality (Sweeney, et al. 1997). Therefore, we hypothesise that:

HYPOTHESIS 2A: Technical audit quality dimensions identified using the gap model (SERVQUAL) will have a significant positive correlation with perceived overall audit quality

HYPOTHESIS 2B: Technical audit quality dimensions identified using the performance-only model (SERVPERF) will have a significant positive correlation with perceived overall audit quality.

\section{Auditor independence}

Independence is the second dimension of DeAngelo's (1981) conceptualisation of two dimensional audit quality. National and regional corporate governance codes and best practices (e.g., Commission of the European Communities (2004); Tabaksblat Committee in the Netherlands (2003); Smith committee of the UK (2003); and the Sarbanes-Oxley Act of 2002 in the US) also require that the audit committee recommend the (re)appointment of the external auditor and ensure his independence. Hence, it seems logical to expect that supervisory directors will assess audit quality as high for those auditors who appeared to be independent. Thus:

HYPOTHESIS 3A: Perceived dimensions of auditor independence identified using the gap model (SERVQUAL) will have a significant positive correlation with assessed overall.

HYPOTHESIS 3B: Perceived dimensions of auditor independence identified using the performanceonly model (SERVPERF) will have a significant positive correlation with assessed overall.

\section{RESEARCH METHOD}

\section{Questionnaire}

The research design involves a structured selfadministered mail questionnaire to a cross-section of supervisory directors of public and non-public 
Asmerom A. Ghebremichael and Fitsum Ghebregiorgis, JTAE, 2017; 1:3

companies. In developing our questionnaire the items of the gap model are adapted by including quality attributes pertaining to the core functions of the audit service, excluding items which, exploratory interviews on the identification of audit quality attributes have suggested to be irrelevant for the our target users of the audit service (supervisory directors), rewording and changing some of the items in the gap questionnaire to enable them reflect the audit function. Using a 7point Likert scale, the questionnaire is designed to provide data on:

- The desired expectation of supervisory directors with regard to the 52 audit quality attributes.

- The perception of supervisory directors about their auditors' performance with regard to the 52 audit quality attributes.

- Supervisory directors' assessment of overall quality of their auditors using a single scale measure of ' 7 ' for excellent and ' 1 ' for poor.

- Supervisory directors' opinion on the independence of their auditors. The assessment is made using two experimental questions on auditor independence. These questions ask whether their auditors would issue a qualified opinion or report to the audit committee if and when certain irregularities discovered are not resolved by the management.

The questionnaire was pre-tested on four supervisory directors to see if it has been presented in a realistic, understandable, and easy to fill-in manner. The participants in the pre-test were able to give us information on the difficulty they encountered in filling-in the questionnaire. All the respondents suggested that the questionnaire was realistic.

\footnotetext{
${ }^{1}$ According to a respondent, there has been an increased interest on the roles of supervisory directors in corporate governance in the Netherlands. As a result, supervisory directors are being
}

\section{Sample and Response}

The EURONEXT-Amsterdam and the REACH (Review and Analysis of Companies in Holland) databases were used to select 1000 supervisory directors who would participate in the survey. For the purpose of identifying the names and addresses of these 1000 supervisory directors, 382 large listed and non-listed companies were selected (151 listed companies from the EURONEXT-database and 231 from the REACHdatabase). Each of these participants was provided with an envelope containing the questionnaire, a covering letter, a self-addressed reply card, and a self-addressed return envelope. The survey instrument was sent in the summer of 2003 to about 1000 supervisory directors and resulted in 69 usable responses. Given the length of the survey questionnaire and the trend of low response rate in surveys that target supervisory directors in the Netherlands, a response rate of about 7 percent ${ }^{1}$ is not surprising.

\section{Data analysis}

In this study we have used descriptive statistical methods (mean and standard deviation) to measure customers' expectation and perception scores. Factor analysis is, then, made in order to reduce the large number of quality attributes into manageable dimensions. These dimensions are then, regressed as independent variables against the dependent variables 'overall service quality' and 'behavioural intensions'.

\section{Reliability and validity}

Ensuring the reliability and validity of the measurement indicators of a concept is crucial for the quality of the research results and inferences made from them. A measurement is reliable when one obtains much the same result on different occasions (de Vaus 1996). However, due to practical reasons, it is often not possible to get

flooded with survey questionnaires and are being less willing to participate. 
Asmerom A. Ghebremichael and Fitsum Ghebregiorgis, JTAE, 2017; 1:3

responses from the same people in different occasions. Thus, de Vaus (1996) suggests that, alternatively, the best way to create reliable indicators is to use multiple-item indicators to measure the one concept and look for consistency of a person's response on the different items. This provides a statistic measure of the overall reliability of the scale called 'Cronbach (coefficient) alpha' with index ranging between 0 and 1 . This statistic is the most commonly accepted measure for assessing the internal consistency of a multi-item measurement scale (Nel, Pitt, and Berthon 1997; Churchill 1979). The higher the alpha the more reliable the measurement scale is with an alpha of 0.70 and above being considered as reliable as a rule of thumb (de Vaus 1996). In this study, we used alpha to measure the reliability of our scales and the results are reported in the next section. The result show that all factors extracted using the two quality measurement models indicated good internal consistency among the variables within each dimension.

The items (attributes) we included and measurement instrument used should also be able to capture the construct we intend to measure (audit service quality). This is what is referred to as the construct validity of the measure. Construct validity pertains to the extent to which a particular measure is rooted in theoretical foundation (de Vaus 1996). The literature review made from the service marketing in and the economics of auditing is for the purpose of identifying attributes of audit service quality that are based on sound theoretical and empirical foundation.

\section{RESULTS}

\section{Dimensions of Audit Quality}

We conduct factor analysis on the 52 quality attributes to reduce them to a manageable number of quality dimensions which are needed for further analysis. The factor analysis is made separately for the technical and functional dimensions because of low response rate. Low response rate limited the use of factor analysis because of large number of variables per respondent (Hair et al. 1998). The suitability of the variables for factor analysis is measured using Bartlett's test of sphericity and KMO measure of sampling adequacy (MSA). The values of these statistics indicate the appropriateness of the variables in the two models for factor analysis (see table 1). Principal components analysis is used in order to get a simplified and uncorrelated variables explaining the quality construct (Hair et al. 1998; Kim and Mueller 1994). Only variables with factor loadings above 0.45 are accepted as belonging to a factor ${ }^{2}$. These dimensions are then regressed as independent variables against the dependent variables 'overall audit quality' to test our hypotheses.

Table 1: Suitability of variables (attributes) in the two models for factor analysis

\begin{tabular}{|l|l|l|l|l|}
\hline \multirow{2}{*}{ Test } & Functional Quality Attributes & \multicolumn{2}{|l|}{ Technical Quality Attributes } \\
\cline { 2 - 5 } & $\begin{array}{l}\text { Performance-only } \\
\text { model }\end{array}$ & Gap model & $\begin{array}{l}\text { Performance-only } \\
\text { model }\end{array}$ & Gap model \\
\hline KMO-MSA & 0.80 & 0.70 & 0.86 & 0.75 \\
\hline $\begin{array}{l}\text { Bartlett's Test of } \\
\text { Sphericity }\end{array}$ & $926.288(0.000)$ & $693.950(0.000)$ & $1431.640(0.000)$ & $1053.803(0.000)$ \\
\hline
\end{tabular}

\footnotetext{
2 There is no absolute rule as to how high a variable's correlation coefficient should be before it is said to lead on a factor. However, it would be unusual to accept variables with lower than 0.30 correlation coefficients (Hair et al. 1998; de Vaus 1996).
} 
Asmerom A. Ghebremichael and Fitsum Ghebregiorgis, JTAE, 2017; 1:3

\begin{tabular}{|l|l|l|l|l|}
\hline No. of variables & 23 & 22 & 23 & 22 \\
\hline No. of factors & 5 & 4 & 4 & 4 \\
\hline Rotation method & Equamax & Varimax & Equamax & Equamax \\
\hline
\end{tabular}

Dimensions of audit quality identified using gap (SERVQUAL) model

Factor analysis on the gap scores resulted in eight factors equally divided between functional quality factors and technical quality factors. The factors are subjectively labelled in an attempt to find an explanation that best reflects the properties shared by the set of variables (attributes) within each factor. An attempt has been made to reduce the subjectivity of the factor labelling by involving more people (academicians and practitioners) in the labelling process. Table 2, panels A and B presents the factor solutions for functional attributes and technical attributes respectively. Only one functional factor (Professionalism) with an alpha of 0.60 violated the minimum 0.70 rule of thumb.

Table 2: Factor solutions for Gap (SERVQUAL) variables;

Panel A: Functional factors

\begin{tabular}{|c|c|c|c|}
\hline $\begin{array}{l}\text { FACTORS } \\
\text { Variables }\end{array}$ & \begin{tabular}{|l|} 
Factor \\
Loadings
\end{tabular} & $\begin{array}{l}\text { Cronbach's } \\
\text { Alpha }\end{array}$ & $\begin{array}{l}\text { Cumulative } \\
\text { Variance }\end{array}$ \\
\hline \multicolumn{4}{|l|}{ RELIABLE AUDIT PROCESS } \\
\hline Regulatory Knowledge & 0.774 & \multirow[t]{7}{*}{0.84} & \multirow[t]{7}{*}{17.6} \\
\hline Good overall reputation & 0.735 & & \\
\hline Meet deadline & 0.699 & & \\
\hline Provisions to keep clients up-to-date & 0.681 & & \\
\hline Audit firm's formal quality procedures & 0.648 & & \\
\hline Knowledge of the internal and external environment of the client & 0.613 & & \\
\hline Ability to be expressive & 0.549 & & \\
\hline \multicolumn{4}{|l|}{ EASY-TO-DEAL-WITH } \\
\hline Accessibility of Auditor to executive directors & 0.660 & \multirow[t]{6}{*}{0.75} & \multirow[t]{6}{*}{31.8} \\
\hline Responsive to the needs of executive directors & 0.658 & & \\
\hline Audit effectiveness & 0.641 & & \\
\hline Reliable in handling client service problems & 0.615 & & \\
\hline Accessibility of auditor to supervisory board & 0.566 & & \\
\hline Responsive to the needs of supervisory board & 0.550 & & \\
\hline \multicolumn{4}{|l|}{ PROVIDING QUALITY INSIGHTS } \\
\hline Comments on the quality of forecasts and targets & 0.813 & \multirow[t]{6}{*}{0.76} & \multirow[t]{6}{*}{44.9} \\
\hline Comments on the quality of executive directors & 0.773 & & \\
\hline Provision of other services & 0.644 & & \\
\hline Bench mark comparisons on the quality of internal control & & & \\
\hline & 0.578 & & \\
\hline Pro-active advice & 0.556 & & \\
\hline
\end{tabular}


Asmerom A. Ghebremichael and Fitsum Ghebregiorgis, JTAE, 2017; $1: 3$

\begin{tabular}{|l|l|l|l|}
\hline Reasonable audit fee & 0.715 & $\mathbf{0 . 6 0}$ & \multirow{5}{*}{$\mathbf{5 5 . 6}$} \\
\cline { 1 - 2 } Active participation in the audit by audit partner & 0.646 & \\
\cline { 1 - 2 } Maintain error free record & 0.551 & \\
\cline { 1 - 2 } Use of client's internal audit & 0.549 & & \\
\hline
\end{tabular}

Panel B: Technical factors

\begin{tabular}{|c|c|c|c|}
\hline $\begin{array}{l}\text { FACTORS } \\
\text { Variables }\end{array}$ & $\begin{array}{l}\text { Factor } \\
\text { Loadings }\end{array}$ & $\begin{array}{l}\text { Cronbach's } \\
\text { Alpha }\end{array}$ & $\begin{array}{l}\text { Cumulative } \\
\text { Variance }\end{array}$ \\
\hline \multicolumn{4}{|l|}{ WHISTLE BLOWING (PUBLIC AGENT) } \\
\hline Report material management fraud to the public & 0.874 & \multirow[t]{7}{*}{0.89} & \multirow[t]{7}{*}{19.8} \\
\hline Report illegal acts to the public & 0.854 & & \\
\hline Report going concern problems to the public & 0.796 & & \\
\hline Report material errors in the financial statements to the public & 0.784 & & \\
\hline Report material employee fraud to the public & 0.761 & & \\
\hline Report earnings management to the public & 0.710 & & \\
\hline Report material deficiencies in internal control to the public & 0.629 & & \\
\hline \multicolumn{4}{|l|}{ DETECTION OF FRAUD AND ILLEGAL ACTS } \\
\hline Detect material management fraud & 0.890 & \multirow[t]{4}{*}{0.88} & \multirow[t]{4}{*}{36.7} \\
\hline Detect illegal acts & 0.859 & & \\
\hline Detect material employee fraud & 0.854 & & \\
\hline Report material management fraud to the supervisory board & 0.524 & & \\
\hline \multicolumn{4}{|l|}{ SUPERVISORY BOARDS' WATCHDOG } \\
\hline Report going concern problems to the supervisory board & 0.775 & \multirow[t]{5}{*}{0.82} & \multirow[t]{5}{*}{51.9} \\
\hline Detect going concern problems & 0.665 & & \\
\hline Provide early warnings of company problems to the supervisory board & 0.630 & & \\
\hline Report illegal acts to the supervisory board & 0.610 & & \\
\hline Report material employee fraud to the supervisory board & 0.569 & & \\
\hline \multicolumn{4}{|l|}{ INTEGRITY IN FINANCIAL REPORTING PROCESS } \\
\hline Detect earnings management in the financial statements & 0.775 & \multirow[t]{6}{*}{0.83} & \multirow[t]{6}{*}{66.6} \\
\hline $\begin{array}{l}\text { Report material errors in the financial statements to the supervisory } \\
\text { board }\end{array}$ & 0.602 & & \\
\hline Report earnings management to the supervisory board & 0.593 & & \\
\hline Detect material deficiencies in internal control & 0.580 & & \\
\hline High level of integrity & 0.563 & & \\
\hline Report material deficiencies in internal control to the supervisory board & 0.530 & & \\
\hline
\end{tabular}

\section{Dimensions of audit quality identified using the performance-only (SERVPERF) model}


Asmerom A. Ghebremichael and Fitsum Ghebregiorgis, JTAE, 2017; $1: 3$

Factor analysis using scores from the factors as measured by Cronbach (alpha) performance-only model resulted in five functional coefficient (de Vaus 1996) and the variance and four technical quality factors. The factors are accounted for by the factors. The minimum 0.7 shown in table 2, panels $A$ and $B$ for functional alpha rule of thumb was violated by two functional attributes and technical attributes respectively. factors (responsiveness and accessibility).

The panels in the table list the reliability of the

Table 3: Factor solution for performance-only variables;

Panel A: Functional factors

\begin{tabular}{|c|c|c|c|}
\hline $\begin{array}{l}\text { FACTORS }^{a} \\
\text { Variables }^{b}\end{array}$ & $\begin{array}{l}\text { Factor } \\
\text { Loadings }\end{array}$ & $\begin{array}{l}\text { Cronbach's } \\
\text { Alpha }\end{array}$ & $\begin{array}{l}\text { Cumulative } \\
\text { Variance }\end{array}$ \\
\hline \multicolumn{4}{|l|}{ RELIABLE AUDIT PROCESS } \\
\hline Maintain error free record & 0.749 & \multirow[t]{6}{*}{0.87} & \multirow[t]{6}{*}{15.8} \\
\hline Knowledge to answer supervisory board's questions & 0.687 & & \\
\hline Audit effectiveness & 0.650 & & \\
\hline Meet deadline & 0.634 & & \\
\hline Responsive to the needs of supervisory boards & 0.589 & & \\
\hline Ability to be expressive & 0.554 & & \\
\hline \multicolumn{4}{|c|}{ COMPANY AND INDUSTRY KNOWLEDGE (Knowledge Dissemination) } \\
\hline Knowledge of the internal and external environment of the client & 0.740 & \multirow[t]{7}{*}{0.86} & \multirow[t]{7}{*}{31.0} \\
\hline Use of client's internal audit & 0.686 & & \\
\hline Provisions to keep clients up-to-date & 0.650 & & \\
\hline Regulatory Knowledge & 0.618 & & \\
\hline Use of international contacts and resources & 0.588 & & \\
\hline Active participation in the audit by audit partner & 0.587 & & \\
\hline Industry specialist & 0.468 & & \\
\hline \multicolumn{4}{|l|}{ RESPONSIVENESS } \\
\hline Reliable in handling client service problems & 0.772 & \multirow[t]{3}{*}{0.69} & \multirow[t]{3}{*}{44.4} \\
\hline Responsive to the needs of executive directors & 0.714 & & \\
\hline Reasonable audit fee & 0.470 & & \\
\hline \multicolumn{4}{|l|}{ PROVIDING QUALITY INSIGHTS } \\
\hline Comments on the quality of forecasts and targets & 0.890 & \multirow[t]{3}{*}{0.78} & \multirow[t]{3}{*}{55.7} \\
\hline Comments on the quality of executive directors & 0.882 & & \\
\hline Bench mark comparisons on the quality of internal control & 0.593 & & \\
\hline \multicolumn{4}{|l|}{ ACCESSIBILITY } \\
\hline A provision for private session & 0.640 & \multirow[t]{4}{*}{0.58} & \multirow[t]{4}{*}{66.1} \\
\hline Good overall reputation & 0.622 & & \\
\hline Accessibility of Auditor to executive directors & 0.618 & & \\
\hline Accessibility of Auditor to supervisory boards & 0.458 & & \\
\hline
\end{tabular}

Note: ${ }^{a}$ Labels in capital letters are factors extracted

$\mathrm{b}$ The statement of the variables are abbreviated in order to make them fit to the table. 
Asmerom A. Ghebremichael and Fitsum Ghebregiorgis, JTAE, 2017; 1:3

Panel B: Technical factors

\begin{tabular}{|c|c|c|c|}
\hline $\begin{array}{l}\text { FACTORS } \\
\text { Variables }\end{array}$ & $\begin{array}{l}\text { Factor } \\
\text { Loadings }\end{array}$ & $\begin{array}{l}\text { Cronbach's } \\
\text { Alpha }\end{array}$ & $\begin{array}{l}\text { Cumulative } \\
\text { Variance }\end{array}$ \\
\hline \multicolumn{4}{|l|}{ WHISTLE BLOWING (Public Agent) } \\
\hline Report material management fraud to the public & 0.917 & \multirow{7}{*}{0.95} & \multirow{7}{*}{24.5} \\
\hline Report illegal acts to the public & 0.912 & & \\
\hline Report material deficiencies in internal control to the public & 0.909 & & \\
\hline Report earnings management to the public & 0.881 & & \\
\hline Report material employee fraud to the public & 0.861 & & \\
\hline Report going concern problems to the public & 0.839 & & \\
\hline Report material errors in the financial statements to the public & 0.820 & & \\
\hline \multicolumn{4}{|l|}{ DETECTION AND REPORTING OF FRAUD AND ILLEGAL ACTS } \\
\hline Report material management fraud to the supervisory board & 0.881 & \multirow{7}{*}{0.93} & \multirow{7}{*}{45.1} \\
\hline Report illegal acts to the supervisory board & 0.847 & & \\
\hline Report material employee fraud to the supervisory board & 0.725 & & \\
\hline Detect illegal acts & 0.719 & & \\
\hline Detect material management fraud & 0.685 & & \\
\hline Detect material employee fraud & 0.623 & & \\
\hline Report going concern problems to the supervisory board & 0.575 & & \\
\hline \multicolumn{4}{|l|}{ INTEGRITY IN FINANCIAL REPORTING PROCESS } \\
\hline $\begin{array}{l}\text { Report material deficiencies in internal control to the supervisory } \\
\text { board }\end{array}$ & 0.807 & \multirow[t]{8}{*}{0.91} & \multirow[t]{8}{*}{65.1} \\
\hline $\begin{array}{l}\text { Report material errors in the financial statements to the } \\
\text { supervisory board }\end{array}$ & 0.741 & & \\
\hline Detect earnings management in the financial statements & 0.708 & & \\
\hline High level of integrity & 0.686 & & \\
\hline Detect material deficiencies in internal control & 0.682 & & \\
\hline Report earnings management to the supervisory board & 0.643 & & \\
\hline Detect going concern problems & 0.612 & & \\
\hline Detect material errors in the financial statements & 0.592 & & \\
\hline \multicolumn{4}{|l|}{ INDEPENDENT ATTITUDE } \\
\hline Independent of all stakeholders & 0.814 & n.a. & 74.6 \\
\hline
\end{tabular}

Hypotheses Testing on the Determinants of The model tests the level of association between Overall Audit Quality

An OLS regression model is used to test hypotheses $\mathrm{H} 1, \mathrm{H} 2$, and $\mathrm{H} 3$. This model has overall audit quality as the dependent variable. functional, technical, and independence factors on one side and overall audit quality perception on the other. This model will be applied in three stages (stage 1, stage 2, and stage 3) based on 
the variables taken as

predictors of the dependent variable. Stage 1 will take all functional, technical, and independence variables; stage 2 will have technical audit quality (auditor competence and independence) factors as independent variables; and stage 3 will take only functional factors as independent variables. The model is stated as follows:

$O A Q_{x}=c+a_{0} F A Q_{p x}+a_{1} T A Q_{p x}+a_{2} I N D_{p x}$

\section{Where:}

$O A Q_{x}=$ Overall audit quality statement for case $x$; $\mathrm{C}=$ Constant;

$F A Q_{p x}=$ Functional audit quality factor score $p$ for case $x$;

TAQpx $=$ Technical audit quality factor score $p$ for case $x$;
$\mathrm{IND}_{\mathrm{px}}=$ Independence statement (factor score) $p$ for case $x$;

\section{The Gap Model}

Table 4 shows the results of the regression model for the gap model variables. The table shows that the gap model variables in the three stages of the regression model explain a significant variance of overall audit quality. Again, the highest prediction is acquired when all the functional, technical, and auditor-independence variables are selected at the same time (stage 1). Unlike the performanceonly model, the most important determinants of overall audit quality in the gap model are functional quality dimensions (reliable audit process, easy-to-deal-with, and professionalism) and auditor independence dimension.

Table 4: Determinants of overall audit quality using gap (SERVQUAL) factors

\begin{tabular}{|c|c|c|c|c|c|c|}
\hline \multicolumn{7}{|c|}{ Model 1: Dependent variable is overall audit quality } \\
\hline \multirow{2}{*}{$\begin{array}{l}\text { Gap (Performance minus } \\
\text { Expectations) factors }\end{array}$} & \multicolumn{2}{|c|}{ Stage 1} & \multicolumn{2}{|c|}{ Stage 2} & \multicolumn{2}{|c|}{ Stage 3} \\
\hline & $\overline{B^{1}}$ & sig. & B & sig. & B & sig. \\
\hline (Constant) & 4.029 & $* * *$ & 4.235 & $* * *$ & 5.324 & $* * *$ \\
\hline Reliable audit process (H1) & 0.409 & $* \star *$ & - & - & 0.438 & $* \star *$ \\
\hline $\begin{array}{l}\text { Bring to the attention of } \\
\text { supervisory } \\
\text { committee }(\mathbf{H} 3)\end{array}$ & 0.221 & $\star \star \star *$ & 0.188 & ** & - & - \\
\hline
\end{tabular}

\begin{tabular}{|c|c|c|c|c|c|c|}
\hline Easy-to-deal-with (H1) & 0.397 & 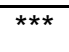 & - & - & 0.435 & 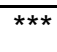 \\
\hline Professionalism (H1) & 0.262 & 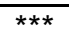 & - & - & 0.316 & $\star \star \star *$ \\
\hline Providing quality insights & -0.044 & & - & - & -0.017 & \\
\hline Whistle blowing/Public agent & -0.002 & & -0.013 & & - & - \\
\hline $\begin{array}{l}\text { Detection of fraud and illegal } \\
\text { acts (H2) }\end{array}$ & 0.015 & & 0.216 & ** & - & - \\
\hline $\begin{array}{l}\text { Supervisory boards' watchdog } \\
\text { (H2/H3) }\end{array}$ & -0.004 & & 0.190 & * & - & - \\
\hline Qualified opinion & -0.073 & & -0.140 & & - & - \\
\hline $\begin{array}{l}\text { Integrity in financial reporting } \\
\text { process }(\mathrm{H} 2 / \mathrm{H} 3)\end{array}$ & -0.018 & & 0.399 & 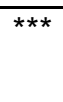 & - & - \\
\hline Observations & 69 & & 69 & & 69 & \\
\hline F-value & 17.266 & $\star \star \star *$ & 9.239 & $\star * \star *$ & 17.775 & $* \star *$ \\
\hline
\end{tabular}


Asmerom A. Ghebremichael and Fitsum Ghebregiorgis, JTAE, 2017; $1: 3$

\begin{tabular}{|l|l|l|l|l|l|}
\hline Adj R-squared & $\mathbf{0 . 4 9 6}$ & $\mathbf{0 . 3 3 0}$ & $\mathbf{0 . 4 2 9}$ & \\
\hline${ }^{* * *},{ }^{* *},{ }^{*}$ : Significance level at $0.01,0.05$, and 0.10 respectively (two-tailed) &
\end{tabular}

Note: $\mathrm{H} 1, \mathrm{H} 2, \mathrm{H} 3$ in parentheses next to the variables indicate that these hypotheses are supported.

Three technical dimensions were also found to be statistically significant determinants of overall audit quality. These are 'integrity in financial reporting process', 'supervisory directors' watchdog', and 'detection of fraud and illegal acts'. The first two dimensions incorporate aspects of auditor independence because they concern both the detection and reporting of errors and irregularities. However, the impact of these dimensions was camouflaged by their multicollinearity with some of the functional dimensions (mainly with the 'reliable audit process' dimension). Once more, those variables which are found to be statistically significant are positively related to overall audit quality. Thus, in the gap model, the hypothesized relationships $(\mathrm{H} 1 \mathrm{~A}, \mathrm{H} 2 \mathrm{~A}$, and $\mathrm{H} 3 \mathrm{~A})$ are supported. Overall audit quality is positively influenced by several of the identified functional, technical, and independence quality dimensions.

\section{The Performance-only Model}

The results of the regression model at the three stages of the model are presented in table 5. The table shows that the variables in the three stages of the model explain a significant variance of overall audit quality. The adjusted R-squared for all three stages are rather high. The highest prediction is acquired when all of the independent variables are selected at the same time (stage 1). The results in table 5 show that, when performance-only variables are considered, the determinants of overall audit quality are mainly related to the auditor's detection ability and independence. The auditor's personal character in terms of his reliability (accuracy and dependability) in the audit process also appears to be important for supervisory directors. In general, the technical quality attributes are found to be the most important determinants of overall audit quality.

Table 5: Determinants of overall audit quality using performance-only factors

\begin{tabular}{|c|c|c|c|c|c|c|}
\hline \multirow[t]{2}{*}{ Performance-only factors } & \multicolumn{2}{|c|}{ Stage 1} & \multicolumn{2}{|c|}{ Stage 2} & \multicolumn{2}{|c|}{ Stage 3} \\
\hline & $\mathrm{B}^{2}$ & sig. & B & sig. & B & sig. \\
\hline (Constant) & 4.341 & *** & 4.396 & *** & 5.333 & *** \\
\hline Integrity in financial reporting process (H2) & 0.398 & *** & 0.476 & *** & - & - \\
\hline Independent attitude (H3) & 0.308 & $* * *$ & 0.379 & *** & - & - \\
\hline Detection and reporting of fraud and illegal acts (H2) & 0.178 & * & 0.198 & ** & - & - \\
\hline $\begin{array}{l}\text { Bring to the attention of supervisory board/audit } \\
\text { committee }(\mathbf{H} 3)\end{array}$ & 0.167 & ** & 0.157 & ** & - & - \\
\hline Reliable audit process (H1) & 0.201 & * & - & - & 0.492 & $* * \star$ \\
\hline Company and industry knowledge (H1) & 0.054 & & - & - & 0.303 & ** \\
\hline Responsiveness (to client's problems) (H1) & 0.102 & & - & - & 0.347 & ** \\
\hline Providing quality insights & 0.012 & & - & - & 0.145 & \\
\hline Accessibility & -0.139 & & - & - & 0.083 & \\
\hline Whistle blowing (Public agent) & 0.107 & & 0.093 & & - & - \\
\hline
\end{tabular}


Asmerom A. Ghebremichael and Fitsum Ghebregiorgis, JTAE, 2017; 1:3

\begin{tabular}{|l|l|l|l|l|l|l|}
\hline Qualified opinion & -0.076 & & -0.082 & & - & - \\
\hline Observations & 69 & & 69 & & 69 & \\
\hline F-value & 14.250 & $* * *$ & 16.180 & $* * *$ & 16.576 & ${ }^{* * *}$ \\
\hline Adj R-squared & $\mathbf{0 . 4 9 3}$ & & $\mathbf{0 . 4 7 2}$ & & $\mathbf{0 . 4 0 7}$ & \\
\hline${ }^{* * *},{ }^{* *},{ }^{*}$ : Significance level at $0.01,0.05$, and 0.10 respectively (two-tailed) \\
\hline
\end{tabular}

Note: $\mathrm{H} 1, \mathrm{H} 2, \mathrm{H} 3$ in parentheses next to the variables indicate that these hypotheses are supported.

It should be noted, however, that there was significant multicollinearity between the 'integrity in financial reporting process' and the 'responsiveness' dimensions (see table A of appendix I). And thus, this multicollinearity has probably masked the impact of the 'responsiveness' dimension on overall audit quality. In addition, there was some degree of multicollinearity between the dimensions 'independent attitude' and 'company and industry knowledge'. Consequently, the latter's impact was not revealed in stage 1 . Stage 3 shows that this is indeed the case as the 'responsiveness' and the 'company and industry knowledge' dimensions became significant predictors when only the functional dimensions are selected in the regression model. Thus, stage 3 appears to hint the importance of these two functional dimensions in supervisory directors' assessment of overall audit quality. All of the statistically significant dimensions influence overall audit quality in the hypothesized direction. Thus, in the performanceonly model also, the three hypotheses with regard to the determinants of overall audit quality $(\mathrm{H} 1 \mathrm{~B}$, $\mathrm{H} 2 \mathrm{~B}$, and H3B) are supported.

\section{Comparison of the Two Quality Measurement Models}

\section{Construct Validity}

The items (attributes) we included and measurement instrument used should be able to capture the construct we intend to measure (audit service quality). Construct validity pertains to the extent to which a particular measure is rooted in theoretical foundation (de Vaus 1996). An integrated literature review has been made for the purpose of identifying attributes of audit quality that are based on sound theoretical and empirical foundation. To this effect, literature on audit quality, audit expectation gap, and service marketing were consulted. Following Churchill (1979), the identification of valid quality attributes from theoretical and empirical literature was augmented by exploratory interviews with experience group.

The process of construct measure validation also involves ensuring the convergent and discriminant validity of the measure. According to Churchill (1979), convergent validity evidences the extent to which a measure correlates highly with other methods designed to measure the same construct. And discriminant validity is the extent to which a measure is novel and not simply a reflection of some other construct. An examination of the correlation matrix in table 6 indicates that the gap model, the performance-only model, and overall service quality are highly correlated with each other showing that the two measurement models possess convergent validity. Again, the performance-only and the gap models showed discriminant validity by having relatively lower correlation with three measures of behavioural intentions of customers which are non-quality concepts.

Table 6: Correlation coefficients for testing convergent and discriminant validity 


\begin{tabular}{l|lllllll}
\hline & & 1 & 2 & 3 & 4 & 5 & 6 \\
\hline 1 & Performance-only model & 1 & & & & & \\
2 & GAP model & .790 & 1 & & & & \\
3 & Overall audit quality & .648 & .545 & 1 & & & \\
4 & Recommend auditor to be retained & .250 & .100 & .329 & 1 & & \\
5 & Recommend the purchase of other services & .248 & .193 & .203 & .191 & 1 & \\
6 & Recommend our auditor to a friend & .437 & .347 & .713 & .386 & .353 & 1 \\
\hline
\end{tabular}

\section{Predictive power}

Consistent with previous service quality studies (e.g., Richard and Allaway 1993; Dassen 1995) and based on the suggestion by de Vaus (1996), we analysed the power of the two quality measurement models on the basis of the coefficient of determination $\left(R^{2}\right)$ of model 1. A summary of the adjusted $\mathrm{R}^{2}$ for the three models is given in table 7. As may be recalled from the sections on hypotheses testing for overall audit quality, the regression model was applied under three alternatives of independent variables (three stages).

Table 7: The predictive power of the two models

\begin{tabular}{|l|l|l|l|}
\hline \multirow{2}{*}{ Model } & \multicolumn{3}{|l|}{ Adj. R-squared for three alternatives of independent variables } \\
\cline { 2 - 4 } & $\begin{array}{l}\text { Functional, technical, } \\
\text { and independence } \\
\text { variables }\end{array}$ & $\begin{array}{l}\text { Technical and } \\
\text { independence variables }\end{array}$ & $\begin{array}{l}\text { Functional } \\
\text { variables }\end{array}$ \\
\hline Performance-only model & 0.493 & 0.472 & 0.407 \\
\hline Gap model & 0.496 & 0.330 & 0.429 \\
\hline
\end{tabular}

The regression model revealed that the explanatory power for the two quality measurement models is improved when they incorporate both functional and technical (and independence) quality dimensions. Contrary to the findings of Cronin and Taylor (1992), the gap model outperformed the performance-only model in explaining perceived overall audit quality when all the variables are considered at the same time. Nevertheless, the difference was marginal. When only the technical and auditor-independence variables are considered, the performance-only model has a much higher explanatory power than the gap model. This is perhaps due to the fact that technical dimensions mainly consist of items that are predefined by statutory and professional audit standards and that the expectations of users has less importance in their measurement. In contrast, the gap model explains slightly more of the variance when only the functional variables are considered.

Therefore, the findings suggest that in a service quality measurement model that incorporates all dimensions of quality, both the performance-only and the gap models can be applied. When only technical dimensions are considered, the performance-only model appears to be more appropriate. On the other hand, when only functional dimensions are considered, then the gap model would be more desirable, although the 
Asmerom A. Ghebremichael and Fitsum Ghebregiorgis, JTAE, 2017; 1:3

performance-only model can also be used with very little loss of explanatory power.

\section{CONCLUSIONS AND IMPLICATIONS}

Our statistical analyses indicated that for both the performance-only and the gap models the functional, technical, and independence factors are positive determinants of overall audit quality. In the search for a suitable quality measurement model for the audit service, the results indicated that both the performance-only model and the gap model have done quite well. The argument by Cronin and Taylor (1992) that the gap model has low explanatory power compared to the performance-only model did not materialise in our study. In fact, the gap model has a slightly better predictive power than the performance-only model in two of the three alternatives of independent variables selection (when all independent variables are selected at the same time and when only functional variables are selected). However, the performance-only model performs well above its counterpart when the variables in consideration are the traditional duties of the auditor as well as auditor independence (technical dimensions). And finally, our analysis indicated that the service marketing models for the measurement of quality would be improved when core outcome (technical) variables are incorporated.

Our results are limited by multicollinearity between some technical and functional quality factors. This is caused by the low response rate that did not allow us to conduct factor analysis on all the functional and technical variables at the same time (see appendix I, table A and table B).

\section{REFERENCES}

Babakus, E. and. Boller, G. W (1992), "An Empirical Assessment of the SERVQUAL Scale", Journal of Business Research, Vol. 24, pp. 253-268.

Bojanic, D. C. (1991), "Quality Measurement in Professional Services Firms", Journal of Professional Services Marketing, Vol. 7 (2), pp. 27-36.
Bolton, R. N. and Drew, J.H. (1991), "A Multistage Model of Customers' Assessment of Service Quality and Value", Journal of Consumer Research, 17, pp. 375-384.

Boshoff, C., Mels, G. and Nel, D. (1994), "The Relative Influence of Service Quality in the Banking Industry", South African Journal of Business Management, (March), Vol. 25, Issue 1.

Buttle, F. (1996), "SERVQUAL: review, critique, research agenda”, European Journal of Marketing, Vol. 30, No. 1, pp. 14.

Carcello, J.V. \& Nagy, A.L. (2004a). "Audit firm Tenure and Fraudulent Financial Reporting". Auditing: A Journal of Practice and Theory, 23, pp. 55-69.

Carcello, J. V., Hermanson, R. H., and McGrath, N. T., (1992), "Audit Quality Attributes: The Perceptions of Audit Partners, Preparers, and Financial Statement Users", Auditing: A Journal of Practice and Theory, (Spring) Vol. 11, No. 1, pp. 1-15.Caruna et al. 1998.

Carman, J. M. (1990), "Consumer Perceptions of Service Quality: An Assessment of the SERVQUAL Dimensions", Journal of Retailing, Vol. 66, (Spring), pp. 33-55.

Caruna, A., B. Ramaseshan, M. T. Ewing, and Rouhani F. (1998), "Expectations about Management Consultancy Services: Testing the Assumptions of Equivalence Across, Australian and Singaporean Firms", Journal of Professional Services Marketing, Vol. 18 (1), pp. 1-10.

Churchill, JR. G. A. (1979), "A Paradigm for Developing Better Measures of Marketing Constructs", Journal of Marketing Research, Vol. XVI, pp. 64-73.

Commission of the European Communities (2004), "Proposal for a Directive of the European Parliament and of the Council on statutory Audit of Annual Accounts and Consolidated Accounts and Amending Council Directives 78/660/EEC and 83/349/EEC", COM (2004) 117, Brussels.

Craswell, A. T., Francis, J. R, and Taylor S. L. (1995), "Auditor Brand Name Reputations and Industrial Specialisations", Journal of Accounting and Economics, 20, pp. 297-322.

Cronin, J. J. \& Taylor, S. A. (1992). "Measuring Service Quality: A Re-examination and extension", Journal of Marketing, 56, pp. 55-68.

Dassen, R. J. M. (1995), “Audit Quality: An Empirical Study of the Attributes and Determinants of Audit Quality Perceptions" (Dissertation, University of Maastricht)

de Vaus, D. A. (1996), "Surveys in Social Research", Fourth Edition, UCL Press Ltd., London. 
Asmerom A. Ghebremichael and Fitsum Ghebregiorgis, JTAE, 2017; 1:3

DeAngelo, L.E. (1981a), "Auditor Size and Audit Quality", Journal of Accounting and Economics, 3, pp. 183-199.

DeFond, M. L. Francis, J. R., and Wong T. J. (2000), "Auditor Industry Specialisation and Market Segmentation: Evidence from Hong Kong", Auditing: A Journal of Practice and Theory, 19, (Spring), pp. 49-66.

Deis, D. R. Jr., and Giroux, G. (1992), "Determinants of Audit Quality in the Public sector", The Accounting Review, 67(3), pp. 462-479.

Duff, A. (2004), "Auditqual, Dimensions of Audit Quality", The Institute of Chartered Accountants of Scotland, Antony Rowe Ltd, Great Britain.

Francis, B. (1996), "SERVQUAL, Review, Critique, Research Agenda", European Journal of Marketing, Vol. 30, Issue 1, p8, 25p.

Grapentine, T. (1998), "The history and future of service quality assessment: connecting customer needs and expectations to business process", Marketing Research, Vol. 10, No 4, pp. 5-10.

Grónroos, C. (1984), "A Service Quality Model and its Marketing Implications", European Journal of Marketing, No. 4, pp. 36-44.

Hair, Jr. J. F., Anderson, R. E., Tatham, R. L. and W. C. Black (1998), "Multivariate Data Analysis", 5 th ed., Prentice-Hall International, Inc. U.S.A.

Herrbach, O. (2001), "Audit Quality, Auditor Behaviour, and the Psychological Contact", The European Accounting Review, 10: 4, pp. 787-802.

Jensen, M.C. \& Meckling, W.H. (1976). "Theory of the Firm: Managerial Behaviour, Agency Costs, and Ownership Structure", Journal of Financial Economics, 3, pp. 305-360.

Kim, J. and Meuller, C. W. (1994), "Factor analysis and Related Techniques”, Edited by M. S. Lewis-Beck, Sage Publications Inc.

Knapp, M. C. (1991), "Factors that Audit Committee Members Use as Surrogates for Audit Quality", Auditing: A Journal of Practice and Theory, Vol. 10, No. 1, pp. 3551.

Krishnan, J. and Schauer, P. C. (2000), "The Differentiation of Quality Among Auditors: Evidence from the Non-for-Profit Sector", Auditing: A Journal of Practice and Theory, Vol. 19. No. 2, pp. 9-25.

Landrum, H., Prybutok, V. R. Kappelman, L. A., and Zhang, X. (2008), SERVCESS: A Parsimonious Instrument to Measure Service Quality and Information System Success. The Quality Management Journal, 15(3), 17-25.
Lehtinen, U. and. Lehtinen, J. R (1991), "Two Approaches to Service Quality Dimensions", The Service Industries Journal, Vol. 11, No. 3, (July), pp. 287-303.

Morton, A.M. (1998), "Audit Service Quality": An Empirical Investigation, PhD. Dissertation, University of Sydney.

Mosahab, R., Mahamad, O. and Ramayah T. (2010), Service Quality, Customer Satisfaction and Loyalty: A Test of Mediation, International Business Research, Vol. 3, No. 4; October, pp. 72-80.

Nagata, H., Satoh, Y. Gerarrd, S. and Kytómaki, P. (2004), "The dimensions that construct the evaluation of service quality in academic libraries", Performance Measurement and Metrics, Vol. 5, No. 2, pp 53-65.

Nel, D., Pitt, L. F. and Berthon, P. R. (1997), "The SERVQUAL Instrument: Reliability and Validity in South Africa", South African Journal of Business Management, Vol. 28, Issue 3, pp. 113 (10p, 6 charts).

Oliver, R. L. (1989), Processing of the Satisfaction Response in Consumption: A suggested Framework and Research Propositions, Journal of Customer Satisfaction, Dissatisfaction, and Complaining Behaviour, 2, pp. 1-16.

Palmrose, Z. (1988), An Analysis of Auditor Litigation and Audit Service Quality, The Accounting Review, Vol. LXIII, No. 1, pp. 55-73.

Parasuraman, A., Zeithaml, V. A., and Berry, L. L. (1994), Reassessment of Expectations as a comparison Standard in Measuring Service Quality: Implications for Further Research, Journal of Marketing, Vol. 58, (January), pp.111-124.

Parasuraman, A., Berry, L. L., and Zeithaml, V. A., (1991a), Perceived Service Quality as a customer-based Performance Measure; An Empirical Examination of Organisational Barriers Using an Extended Service Quality Model, Human Resource Management, Vol. 30, No. 3, (Autumn), pp. 335-64.

Parasuraman, A., Zeithaml, V. A., and Berry, L. L. (1991b), Refinement and Reassessment of the SERVQUAL Scale, Journal of Retailing, Vol. 67, No. 4, (Winter), pp.420-450.

Parasuraman, A., Zeithaml, V. A., and Berry, L. L. (1990), An Empirical Examination of Relationships in Extended Service Quality Model, Marketing Science Institute, Cambridge, MA.

Parasuraman, A., Zeithaml, V. A., and Berry, L. L. (1988), SERVQUAL: A Multiple-Item Scale for Measuring Consumer Perceptions of Service Quality, Journal of Retailing, Vol. 64, No1, (Spring), pp. 12-40. 
Asmerom A. Ghebremichael and Fitsum Ghebregiorgis, JTAE, 2017; 1:3

Parasuraman, A., Zeithaml, V. A., and Berry, L. L. (1985), A Conceptual Model of Service Quality: Implications for Future Study, Journal of Marketing, 49 (Fall), pp. 41-50.

Ravichandran, K., Mani, B. T., Kumar, S. A. and Prabhakaran, S. (2010), "Influence of Service Quality on Customer Satisfaction: Application of SERVQUAL Model", International Journal of Business and Managemen,t Vol. 5, No. 4; pp. 117-124.

Richard, M. D. and Allaway, A. W. (1993), "Service Quality Attributes and Choice Behaviour", Journal of Service Marketing, Vol. 7., no. 1, pp. 59-68.

Sadchev, S. B. and Verma, H. V. (2002), "Customers Expectations and Service Quality Dimensions Consistency", Journal of Management Research, Vol. 2, No. 1, (April), pp. 43-52.

Saleh, F. and C. Ryan (1991), "Analysing Service Quality in the Hospitality Industry Using the SERVQUAL Model", Service Industries Journal 11, (July), pp. 324-343.

Simon, D. T. (1997), "Additional Evidence on the Large Audit Firm Fee Premium as an Indicator of Auditor Quality", Journal of Applied Business Research (Fall), Vol. 13, p21, 9p.

Smith R. (2003), Audit Committees, Combined Code Guidance, The Financial Reporting Council, UK.

Stank, T. P., Goldsby, T. J. and Vickery, S. K. (1999), "Effects of Service Supplier Performance on Satisfaction and Loyalty of Store Managers in the Fast Food Industry", Journal of Operations Management, 17, pp. 429-447.

Sweeney, J. C., Soutar, G. N. and Johnson, L. W. (1997), "Retail Service Quality and Perceived Value", Journal of retailing and Consumer Services, Vol. 4, No. 1, pp. 3948.

Tabaksblat Committee (2003), "The Dutch Corporate Governance Code: principles of good corporate governance and best practice provisions"; www.commissiecorporategovernance.nl.

Teas, R. K. (1993a), "Expectations, Performance Evaluation, and Consumers Perceptions of Quality", Journal of Marketing, Vol. 57, (October), pp. 18-34.

Teas, R. K. (1993b), "Consumer Expectations and Measurement of Perceived Service Quality", Journal of Professional Service Marketing, Vol. 8, No. 2, pp. 33-53.

Urdang, B. S. and Howey, R. M. (2001), "Assessing Damages for Non-performance of a travel Professionala Suggested Use of SERVQUAL", Tourism Management, 22, pp. 533-538.

Vanstraelen, A. (2000), "Impact of Renewable Long-term Audit Mandates on Audit Quality", The European
Accounting Review, 9: 3, pp. 419-442.

Warming-Rasmussen, B. \& Jensen, L. (1998). Quality Dimensions in External Audit Services-An External User Perspective. The European Accounting Review, 7, 6582.Watkins, Hillison, and Morecroft 2004).

Watts, R. L. and Zimmerman J. L. (1981), "The Market for Independence and Independent Auditors", Working Paper, University of Rochester.

Woo, K. and Ennew C. T. (2005), "Measuring Businessto-Business Professional Service Quality and its Consequences", Journal of Business Research, 58, pp. 1178-1185.

Wooten, T. C. (2003), "Research about Audit Quality", The CPA Journal, Vol. 73, Issue 1, pp. 48-51.

Zeithaml, V. A. (2000), Service Quality, Profitability, and the Economic Worth of Customers: What We Know and What We Need to Learn, Journal of the Academy of Marketing Science, Vol. 28, No. 1, pp. 67-85.

Zeithaml, V. A., Berry, L. L, and Parasuraman, A., (1996), "The behavioural Consequences of Service Quality", Journal of Marketing, Vol. 60 (April), pp. 31-46.

Zeithaml, V. A., Parasuraman, A., and Berry, L. L., (1990), "Delivering Quality Service", New York Free Press. NY.

Zeithaml, V. A., Berry, L. L, and Parasuraman, A., (1988), "A Communication and Control Processes in the Delivery of Service Quality", Journal of Marketing, 52, 35-48. 
Asmerom A. Ghebremichael and Fitsum Ghebregiorgis, JTAE, 2017; 1:3

Appendix I: Indications of multicollinearity among some technical and functional factors.

Table A: Correlation matrix for gap (SERVQUAL) factors

\begin{tabular}{l|llllllllll}
\hline & 1 & 2 & 3 & 4 & 5 & 6 & 7 & 8 & 9 & 10 \\
\hline 1 & Reliable service (Auditor reliability) & - & & & & & & & & \\
2 & Attention to client &, 000 & - & & & & & & & \\
3 & Providing quality insights &, 000 &, 000 & - & & & & & & \\
4 & Professionalism &, 000 &, 000 &, 000 & - & & & & & \\
5 & Public agent/Whistle blowing &,- 057 &, 063 &, $364^{* *}$ &,- 038 & - & & & & \\
6 & Detection of fraud and illegal acts &, $253^{*}$ &, 145 &, $415^{* *}$ &, 134 &, 000 & - & & & \\
7 & Supervisory directors' watchdog &, 206 &, 137 &, $344^{* *}$ &, 182 &, 000 &, 000 & - & & \\
8 & Integrity in financial reporting &, $284^{*}$ &, $526^{* *}$ &,- 070 &, $285^{*}$ &, 000 &, 000 &, 000 & - \\
9 & Qualified opinion &, 036 &,- 033 &, 186 &, 100 & - &, 030 & - &, $253^{*}$ & - \\
& & & & & &, 147 & &, 013 & & \\
10 & Bring to the attention of supervisory &, 115 &, 062 &, 142 &, 213 & - &, 181 &, 119 &, $292^{*}$ &, $387^{* *}$ \\
& directors & & & & &, 047 & & & & \\
\hline
\end{tabular}

${ }^{* \star},{ }^{*}$ : Correlation is significant at the 0.01 and 0.05 levels respectively (2-tailed).

Table B: Correlation matrix for performance-only (SERVPERF) factors

\begin{tabular}{|c|c|c|c|c|c|c|c|c|c|c|c|c|}
\hline & & 1 & 2 & 3 & 4 & 5 & 6 & 7 & 8 & 9 & 10 & 11 \\
\hline 1 & Reliable service & - & & & & & & & & & & \\
\hline 2 & $\begin{array}{l}\text { Company and industry } \\
\text { knowledge }\end{array}$ &, 000 & - & & & & & & & & & \\
\hline 3 & Responsiveness &, 000 &, 000 & - & & & & & & & & \\
\hline 4 & Providing quality insights &, 000 &, 000 &, 000 & - & & & & & & & \\
\hline 5 & Accessibility &, 000 &, 000 &, 000 &, 000 & - & & & & & & \\
\hline 6 & Public agent/Whistle blowing &,- 075 &,- 083 &, 082 &, $536^{\star *}$ &,- 134 & - & & & & & \\
\hline 7 & $\begin{array}{l}\text { Detection and reporting of } \\
\text { fraud and illegal acts }\end{array}$ & ,090 & ,188 & ,104 &, $391^{* *}$ & ,090 &, 000 & - & & & & \\
\hline 8 & Integrity in financial reporting &, $369^{* *}$ & ,137 &, $593^{\star \star}$ & ,072 &, $382^{* *}$ & ,000 &, 000 & - & & & \\
\hline 9 & Independent attitude &, $354^{* *}$ &, $495^{* *}$ &,- 056 &,- 029 &,- 082 &, 000 &, 000 & ,000 & - & & \\
\hline 10 & Qualified opinion &,- 005 & , 155 & ,051 & ,130 &, $260^{*}$ & ,058 &,- 018 & ,189 &,- 071 & - & \\
\hline 11 & $\begin{array}{l}\text { Bring to the attention of } \\
\text { supervisory directors }\end{array}$ & ,092 & ,135 & 235 & 232 & ,269* &, 087 & ,162 &, $327^{\star *}$ & ,021 &, $387^{\star *}$ & - \\
\hline
\end{tabular}

${ }^{* *},{ }^{*}$ : Correlation is significant at the 0.01 and 0.05 levels respectively (2-tailed) 